\section{CLINICAL AND EPIDEMIOLOGICAL FEATURES OF HERPESVIRUS INFECTIONS}

M.D. Chemych, V.V. Ilyina, M.V. Lymar

SUMMARY. Analyzed the clinical features of herpesvirus infections (HVI). It was established that the HVI often ill women over 40 years. The cause of disease is the primary form of contact with a sick person, reactivation of infection is due to hypothermia, ARVI, neuro-emotional stress. With clinical forms of chronic prevails (reactivated). In patients with HSV-3 frequently diagnosed form of spinal localization process over the course of the intercostal nerves. Complications are more common HVI caused by HSV-1.

Key words: herpesvirus infections, clinical features.

Отримано 27.11.2015 p.

\title{
ПАТОГЕНЕТИЧНІ ПІДХОДИ ДО ЛІКУВАННЯ РОТАВІРУСНОЇ ІНФЕКЦІї У ДІТЕЙ
}

Вінницький національний медичний університет ім. М.І. Пирогова

Наведено результати лікування 134 дітей віком від 3 міс. до 5 років з діагнозом ротавірусної інфекції. Досліджено ефрективність використання схеми терапії ротавірусної інфекції у дітей з комбінації Saccharomyces boulardii ma суміші NAN безлактозний на основі аналізу клінічної симптоматики та лабораторних показників. Встановлено, що використання такого поєднання сприяє зменшенню тривалості основних клінічних проявів рота-вірусної інфекції (PBI) та прискорює елімінацію вірусу з кишечнику.

Ключові слова: ротавірусна інфрекція, безлактозне харчування, діти.

У структурі інфекційної захворюваності дітей, особливо раннього віку, одне з пріоритетних місць стабільно займають гострі кишкові інфекції [1]. щорічно у світі реєструється приблизно 1,4 млрд випадків гострої діареї у дітей перших п'яти років життя. Понад 475 млн випадків 3 них припадає на дітей першого року життя $[2,3]$. В етіологічній структурі гострих гастроентеритів частка вірус-асоційованих інфеекцій складає 30-50\%. Збудниками діарейних захворювань у 24,0-35,5\% випадків є ротавіруси, у 17,6-24,1 \% - норовіруси, у 19,1\% - аденовіруси, у 3,7-8,9 \% - астровіруси [4-6]. На підставі аналізу даних за 2008 р. встановлено, що РВІ стала причиною 453000 смертей дітей молодшого віку, що склало 5 \% від усіх летальних випадків [7]. Враховуючи серйозність соціально-медичної проблеми $\mathrm{PBI}, 3$ 2008 р. ВООЗ здійснює координацію Глобальної мережі стеження за РВІ.

Патогенез РВІ складний і не до кінця вивчений, особливо метаболічні та біохімічні процеси, що відбуваються в просвіті кишечнику та призводять до розвитку дисахаридазної недостатності у дітей.

Надмірне надходження лактози при РВІ, внаслідок дефіциту ферменту лактази, в товсту кишку приводить до кількісної та якісної зміни складу мікрофрлори і підвищення осмотичного тиску в просвіті товстої кишки 3 розвитком клінічних проявів непереносимості лактози [8-11]. Накопичення нерозщепленої лактози в просвіті кишечнику супроводжується розвитком метаболічного дисбалансу з утворенням великої кількості органічних кислот [12], що приводить до зниження рН інтестинального вмісту та посилення перистальтики [7]. Встановлено, що лактазна недостатність (ЛН) у дітей супроводжується порушенням усіх етапів і рівнів травлення: порожнинного, пристінкового, внутрішньоклітинного [10, 13].

Таким чином, проблема розвитку лактазної недостатності у дітей раннього віку є ключовою ланкою патогенезу ротавірусної інфрекції.

Основними напрямками лікування РВІ на сучасному етапі є: поповнення десріциту рідини, ентеросорбція, 
пробіотична, імунотропна терапія та дієтичне харчування [14]. Лікувальне харчування є дуже важливим компонентом комплексної терапії у дітей, хворих на РВІ. Об'єм і склад харчування визначається віком дитини, тяжкістю захворювання та видом вигодовування. Загальні принципи харчування при РВІ не відрізняються від основних постулатів при ГКІ іншої етіології, хоча мають свої особливості. Згідно даних С.В. Халіулліної, у 85 \% дітей з РВІ спостерігається розвиток ЛН. Беручи до уваги важливу роль вторинної ЛН у патогенезі РВІ, новим підходом в лікуванні дітей є застосування низько- та безлактозних сумішей для харчування, а також дотація лактози [12]. Застосування таких продуктів харчування у дітей, що знаходяться на штучному та змішаному вигодовуванні, покращує перебіг даного захворювання та пришвидшує клінічне одужання. Що стосується дітей, які знаходяться на грудному вигодовуванні, пріоритетним напрямком є дотація фрерменту лактаза-фрлоризингідролаза. Шадрін О.Г. зі співав. (2011 р.) довели, що використання препаратів, які містять даний фрермент, веде до більш швидкого одужання і покращує загальний стан дитини [15].

Пероральна регідратація є фрізіологічною медикаментозною терапією, адже було показано тісну взаємодію транспортних механізмів натрію і глюкози в ентероцитах. Йони $\mathrm{Na}^{+}$більш ефективно всмоктуються 3 просвіту кишечнику транспортером SGLT1 в присутності глюкози. Нееорективність оральної регідратації протягом доби є показанням для призначення парентерального введення глюкозо-сольових розчинів. Поповнення деоріциту рідини проводиться з урахуванням втрат рідини та типу ексикозу [16].

Іншою важливою складовою лікування PBI € призначення ентеросорбентів (смекта, полісорб, атоксіл, ентеросгель, біле вугілля та ін.) Сорбенти зв'язують і виводять 3 шлунково-кишкового тракту (ШКТ) збудників, а також продукти їх метаболізму. Вони не всмоктуються $з$ шлунково-кишкового тракту, повністю виводяться через 24-48 год, не пригнічують нормальної фрлори кишечнику, при РВІ рекомендується використовувати ентеросорбенти з групи активованого вугілля, враховуючи їх високу сорбційну активність щодо ротавірусів і патогенних бактерій в шкТ [17]. На основі результатів багатьох рандомізованих, плацебо-контрольованих, порівняльних досліджень визнана ефективність призначення пробіотичної терапії для лікування РВІ у дітей. Встановлено, що пробіотична терапія достовірно сприяє процесу одужання дітей з РВI, так, на думку Stefano Guandalini, при лікуванні PBI найбільш ефективними є препарати, що містять у своєму складі Lactobacillus rhamnosus GG (LGG) i Saccharomyces boulardii [18]. Giuseppe Grandi та співав. продемонстрували, що клінічна ефективність лікування дітей з РВI препаратами, що містять Saccharomyces boulardii, значно перевищує ефрективність використання інших пробіотичних препаратів [19]. Дослідження Урсової Н.І. (2008 р.) показали, що Saccharomyces boulardii має пряму дію на слизову оболонку тонкої кишки, на її трофрічні та ферментативні резерви [20].

Таким чином, S. boulardii завдяки своїм фрізіологічним ефректам впливає практично на всі фрази патогенезу РВI і тому може виправдано призначатися для патогенетичного лікування.

\section{Пацієнти і методи}

Дослідження проводилось на базі Вінницької обласної клінічної дитячої інфекційної лікарні на кафедрі дитячих інсрекційних хвороб ВНМУ ім. М.І. Пирогова (завідувач кафредри - д.мед.наук., проф. Незгода І.І.). За період 3 грудня 2013 р. по червень 2014 р. проліковано 134 хворих на ротавірусну інсрекцію. Лікування хворих проводили згідно з протоколами лікування ГКІ та доповненнями, затвердженими наказом МОЗ України від 10.12.2007 р. № 803.

Під час проведення наукового дослідження обстежуваний контингент хворих був розподілений на 2 групи. Першу, контрольну групу, склали 66 дітей, які при госпіталізації до стаціонару отримували базисну терапію відповідно до протоколів лікування. Другу, основну групу, склали 68 дітей, які отримували, крім базисної терапії, розроблену нами схему лікування із застосуванням Saccharomyces boulardii у вигляді препарату Ентерол (виробник: Biocodex Lab., Франція; реєстраційний № UA/6295/01/01 від 13.06.2012) та специфічного харчуваня сумішшю NAN безлактозний (Nestle, Швейцарія). Препарат застосовували з першої доби госпіталізації, відповідно до віку: діти до року отримували 125 мг (1/2 пакетика) 2-3 рази на добу, діти старші року 250 мг (1 пакетик) 2 рази на добу. Суміш NAN безлактозний застосовували у вигляді основного харчування у дітей віком від 3 до 6 міс., у дітей більш старших вікових груп суміш застосовували як додаток до харчового раціону 3 рази на добу у віковому об'ємі. Всі діти були виписані зі стаціонару з клініко-лабораторним одужанням, не зареєстровано жодного летального випадку.

\section{Результати досліджень та їх обговорення}

У процесі наукового дослідження виявлено, що основними клінічними проявами захворювання були гарячка, блювота і діарея. Тривалість симптомів, залежно від виду терапії, представлена в таблиці 1. Порівняльний аналіз клінічної ефективності запропонованих схем лікування показав, що у хворих основної групи швидше, ніж контрольної, зникали симптоми інтоксикації та ознаки диспепсичного синдрому.

Як видно з даних, наведених у таблиці 1, тривалість діареї у хворих на тлі застосування схеми лікування: 


\section{ОРИГІНАЛЬНІ ДОСЛІДЖЕННЯ}

комбінації Saccharomyces boulardii та суміші NAN безлактозний становила $(2,79 \pm 0,12)$ проти $(4,50 \pm 0,18)$ доби $(\mathrm{p}<0,001)$ у хворих контрольної групи, тобто нормалізація консистенції випорожнень у дітей основної групи відбулася вдвічі швидше.

Таблиця 1

Порівняльна характеристика тривалості основних клінічних симптомів PBI у дітей

\begin{tabular}{|c|c|c|}
\hline \multirow[b]{2}{*}{ Симптом } & \multicolumn{2}{|c|}{ 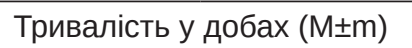 } \\
\hline & $\begin{array}{c}\text { Основна } \\
\text { група } \\
\text { n=68 }\end{array}$ & $\begin{array}{c}\text { Контрольна } \\
\text { група } \\
\text { n }=66\end{array}$ \\
\hline Діарея & $2,79 \pm 0,12$ & $4,50 \pm 0,18^{* *}$ \\
\hline Гарячка & $2,07 \pm 0,14$ & $2,84 \pm 0,22^{*}$ \\
\hline Блювання & $1,44 \pm 0,11$ & $1,83 \pm 0,16^{*}$ \\
\hline Бурчання в животі & $1,86 \pm 0,11$ & $3,62 \pm 0,22^{\star *}$ \\
\hline Метеоризм & $1,62 \pm 0,09$ & $3,19 \pm 0,18^{* *}$ \\
\hline
\end{tabular}

Примітка. * - p<0,05 - різниця між тривалістю симптомів в основній і контрольній групах,

** - різниця між тривалістю симптомів в основній і контрольній групах $(p<0,001)$.

У дітей основної групи підвищення температури тіла мало місце протягом $(2,07 \pm 0,14)$ доби, тоді як у дітей контрольної групи температурна реакція зберігалась впродовж $(2,84 \pm 0,22)$ доби, що на 0,67 доби довше, причому різниця була достовірною $(p<0,05)$ між порівнюваними групами дітей.

У дітей, які отримували дану схему лікування, блювання зникало достовірно швидше, ніж у дітей

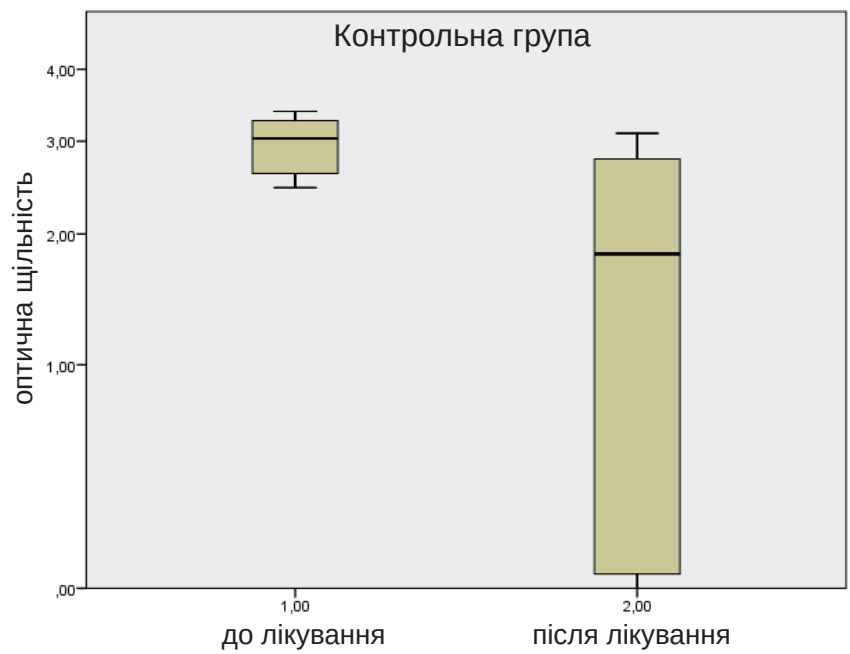

Мал. 1. Оптична щільність випорожнень у дітей на початку лікування та на 5-у добу терапії.

Отже, у дітей, які отримували крім базисної терапії суміш NAN безлактозний у комбінації з Saccharomyces контрольної групи - $(1,44 \pm 0,11)$ проти $(1,83 \pm 0,16)$ доби, $\mathrm{p}<0,05$.

Бурчання в животі та метеоризм безпосередньо пов'язані з ферментною недостатністю та синдромом мальабсорбції при РВІ у дітей. Так, у хворих основної групи бурчання в животі відмічали впродовж $(1,86 \pm 0,11)$ діб, тоді як у дітей, які не отримували відповідного безлактозного харчування та Saccharomyces boulardii, цей симптом спостерігався достовірно довше

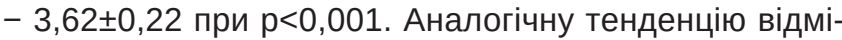
чали також і щодо тривалості метеоризму, в основній групі він тривав $(1,62 \pm 0,09)$ дні, а у дітей контрольної групи - $(3,19 \pm 0,18)$ доби ( $<<0,001)$, тобто реєструвався на 1,57 доби довше.

Важливим показником ефективності лікування PBI, крім клінічних особливостей, є елімінація збудника з кишечнику, адже чим скоріше організм звільняється від збудника, тим швидше відбувається регрес клінічної симптоматики та покращення лабораторних показників. З'ясувавши клінічні особливості у групах порівняння, ми провели аналіз оптичної щільності випорожнень, що свідчить про кількість вірусу в кишечнику дитини.

У дітей, які отримували базисну терапію, оптична щільність випорожнень становила $(2,76 \pm 0,22)$ мг/мл, а на 5-у добу після початку лікування оптична щільність зменшилась до $(1,52 \pm 0,32)$ мг/мл. В основній групі дітей, що отримували безлактозну суміш та Saccharomyces boulardii, оптична щільність випорожнень до початку лікування становила $(2,18 \pm 0,20)$ мг/мл, а от на 5-у добу лікування вона достовірно зменшувалась до $(0,60 \pm 0,16)$ мг/мл при р<0,05 (мал. 1).

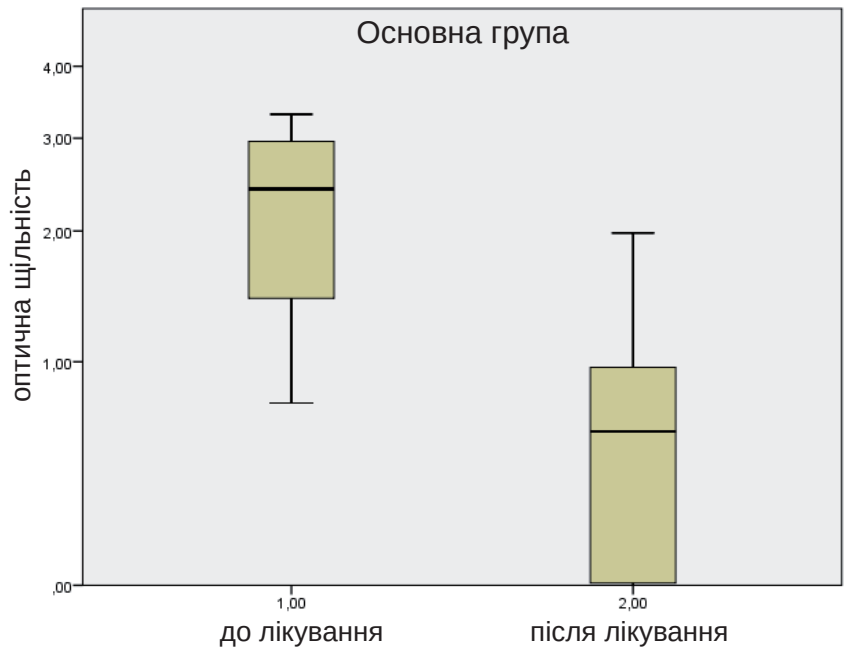

boulardii, вже на 5-у добу лікування кількість вірусного антигену у випорожненнях була меншою, ніж у дітей, що 
отримували лише базисну терапію, тобто у дітей основної групи скоріше відбувалось звільнення організму від вірусу.

Швидка динаміка провідних симптомів захворювання у дітей основної групи, а також більш швидке покращення клініко-лабораторних показників дозволили зменшити тривалість захворювання $3(6,45 \pm 0,21)$ доби у дітей контрольної групи до $(5,31 \pm 0,20)$ доби у дітей основної, що на 1,14 доби менше, p<0,05.

Отже, в результаті проведеного дослідження встановлено, що призначення схеми лікування із застосуванням суміші NAN безлактозний у комбінації з Saccharomyces boulardii при лікуванні дітей з РВІ сприяло швидшому покращенню загального стану хворих, скороченню тривалості лихоманки, кратності та тривалості блювоти, діарейного синдрому, а також зникненню явищ токсикозу та ексикозу, скоротились також строки видалення вірусу на основі аналізу оптичної щільності випорожнень (ІФА).

\section{Висновки}

1. Ротавірусна інфрекція є найбільш розповсюдженою причиною тяжкої дегідратаційної діареї у дітей раннього віку.

2. Розвиток лактазної недостатності у дітей раннього віку $є$ ключовою ланкою патогенезу ротавірусної інфекції, тому велике значення в базисній терапії РВІ, крім ентеросорбентів і пробіотичних препаратів, має безлактозне харчування.

3. Призначення схеми лікування сумішшю NAN безлактозний в комбінації з препаратом Saccharomyces boulardii сприяє швидшій ліквідації основних клінічних симптомів PBI у дітей, а саме: зменшує тривалість блювання та сприяє вдвічі швидшій нормалізації консистенції випорожнень, таким чином дає змогу скоротити термін стаціонарного лікування дітей в середньому на 1,14 доби порівняно з групою дітей, які отримували базисну терапію.

4. Результати лікування при РВІ комбінацією безлактозного харчування (NAN безлактозний) та Saccharomyces boulardii свідчать про ії ефективність і доцільність при вказаній патології. Схема лікування добре переноситься хворими, зручна та проста у дозуванні та застосуванні, небажаних ефректів не спостерігалось.

\section{Література}

1. Крамарев С.А. Ротавирусная инсекция: эпидемиология и профилактика / С.А. Крамарев, Л.В. Закордонец // Здоровье ребенка. - 2011. - № 1 (28). - С. 53-55.

2. Economic and psychosocial impact of rotavirus infection in Spain: a literature review / [J. Álvarez Aldeán, J. Aristegui, J. L. LópezBelmonte et al.] // Vaccine. - 2014. - Vol. 32, N 30. - P. 3740-3751.
3. Global illness and deaths caused by rotavirus disease in children I [U.D. Parashar, E.G. Hummelman, J.S. Bresee et al.] // Emerg. Infect. Dis. - 2003. - Vol. 9, N 5. - P. 565-572.

4. Асилова М.У. Вирусные диареи в структуре острых кишечных инфекций у детей / М.У. Асилова, Э.И. Мусабаев, Г.Б. Убайдуллаева // Журн. инфектологии. - 2011 - № 3. - С. 56-59.

5. Вирусные диареи у детей и взрослых / под ред. В.П. Малого. - СПб, 2011. -104 с.

6. Горелов А.В. Ротавирусная инфекция у детей / А.В. Горелов, Д.В. Усенко // Вопр. совр. педиатрии. - 2008. - Т. 7, № 6. - С. 7884.

7. 2008 estimate of worldwide rotavirus-associated mortality in children younger than 5 years before the introduction of universal rotavirus vaccination programmes: a systematic review and metaanalysis / [J.E. Tate, A.H. Burton, C. Boschi-Pinto et al.] // Lancet Infect. Dis. - 2012. - Vol. 12, N 2. - P. 136-141.

8. Лукьянова А.М. Клинико-эпидемиологическая характеристика вирусных диарей у детей / А.М. Лукьянова, М.К. Бехтерева, Н.Н. Птичникова // Журн. инфектологии. - 2014. - Т. 6, № 1. C. 60-66.

9. Мазанкова Л.Н. Ротавирусная инсекция у детей на современном этапе: клиника, диагностика, лечение / Л.Н. Мазанкова, Н.О. Ильина // Вопр. практич. педиатрии. - 2010. - Т. 5, № 6. C. $43-49$.

10. Мазанкова Л.Н. Современные аспекты диагностики и лечения острых кишечных инфекций у детей / Л.Н. Мазанкова, Н.О. Ильина // Рос. вестник перинатологии и педиатрии. - 2007. - № 2. - C. 4-10.

11. Незгода I.I. Патогенетична та клініко-імунологічна характеристика застосування Saccharomyces boulardii при ротавірусній інфекції у дітей / І.І. Незгода, О.В. Боднарюк // Клінічна імунологія, алергологія та інфектологія. - 2014. - № 5 (74). - С. 37-41.

12. Халиуллина С.В. Вторичная лактазная недостаточность В клинике ротавирусных кишечных инсекций у детей / С.В. Халиуллина, В.А. Анохина, И.А. Гутор // Практич. медицина. - 2010. - № 6 (45). - C. $44-47$

13. Мазанкова Л.Н. Ротавирусная инсекция у детей раннего возраста: обоснование пробиотической терапии / Л.Н. Мазанкова, Г.Ю. Яковлева, М.Д. Ардатская // Детские инфрекции - 2011. - Т. 10, № 2. - С. 52-56.

14. Васильев Б.Я. Острые кишечные заболевания. Ротавирусы и ротавирусная инфекция / Б.Я. Васильев, Р.И. Васильева, Ю.В. Лобзин. - СПб : Лань, 2000. - 268 с.

15. Проблемні питання перебігу та терапії лактазної недостатності у дітей раннього віку / [О.Г. Шадрін, Т.Л. Марушко, В.П. Місник та ін.] // Совр. педиатрия. - 2011. - № 6. - С. 157-161.

16. Куличенко Т.В. Ротавирусная инфекция у детей / Т.В. Куличенко // Вопросы диагностики в педиатрии. - 2009. - № 2. C. $17-23$

17. Абатуров А.Е. Ротавирусная инфекция у детей : монография / А.Е. Абатуров, Ю.Ю. Степанова. - К., 2013. - 232 с.

18. Guandalini S. Probiotics for prevention and treatment of diarrhea / S. Guandalini // J. Clin. Gastroenterol. - 2011. - N 45. P. $149-153$.

19. Probiotics in the treatment of acute rotavirus diarrhoea. A randomized, double-blind, controlled trial using two different probiotic preparations in Bolivian children. [G. Grandy, M. Medina, R. Soria et al.] // BMC Infect. Dis. - 2010. - Vol. 25. N 10. - P. 253-254.

20. Урсова Н.И. Антибиотико- ассоциированная диарея: выбор пробиотика с позиций медицины, основанной на доказательствах / Н.И. Урсова // Трудный пациент - 2013. - № 2-3. - С. 19-24. 


\section{PATHOGENETIC APPROACHES TO THE TREATMENT OF ROTAVIRUS INFECTION IN CHILDREN}

O.M. Naumenko

SUMMARY. The results of treatment of 134 children aged 3 months to 5 years with a diagnosis of rotavirus infection. Efficiency scheme using a combination of Saccharomyces Boulardii mixture NAN lactose-free and treatment of rotavirus infection in children by analyzing the clinical symptoms and laboratory parameters. It is established that the use of a mixture of NAN lactose-free combined with Saccharomyces Boulardii significantly reduces the length of the main clinical manifestations and RVI accelerates the elimination of the virus from the gut.

Key words: rotavirus infection, lactose-free diet, children.

Отримано 24.02.2016 р.

\section{ЗМІНИ ЕТІОЛОГІЧНОГО СПЕКТРУ ЗБУДНИКІВ ЛЕПТОСПІРОЗУ СЕРЕД НАСЕЛЕННЯ НА ТЕРНОПІЛЛІ}

Тернопільський державний медичний університет ім. І.Я. Горбачевського, ДУ «Тернопільський обласний лабораторний центр ДСЕС України»

Тернопільська область $є$ ендемічною по лептоспірозу. Ії природні умови (слабколужні чи лужні ґрунти, температура повітря, достатня кількість опадів) сприяють існуванню основного природного резервуара збудника - мишоподібних гризунів. На території області постійно виділяються різні сероваріанти лептоспір від гризунів і сільськогосподарських тварин. Проведений аналіз циркуляції збудників хвороби між різними джерелами (гризуни, інші тварини) і щорічної захворюваності населення свідчить про те, що нові серовари лептоспір заносяться здебільшого сільськогосподарськими тваринами, від яких через довкілля інфікується людина, іноді з інтервалом 3-5 років; спостерігається подальше розповсюдження нових для даної території сероварів збудника у всіх видів обстежених мишоподібних гризунів. Встановлено, що сільськогосподарські тварини і гризуни є конкуруючими резервуарами. Для прогнозування подальшої епідситуації з лептоспірозу серед населення та покращення його діагностики необхідний постійний моніторинг чисельності, інфрікованості та лептоспіроносійства серед мишоподібних гризунів і сільськогосподарських тварин й розширення набору діагностичних штамів лептоспір з урахуванням нових варіантів збудників у тварин.
Ключові слова: лептоспіроз, захворюваність населення, джерела інфекції, мишоподібні гризуни, сільськогосподарські тварини.

Лептоспіроз - широко розповсюджене інсекційне захворювання як серед людей, так і у тварин. Хвороба характеризується переважно тяжким перебігом, високою летальністю, надає великі соціальні та економічні збитки. За деякими оцінками, щорічно у світі реєструється серед населення 1,03 млн випадків і 58900 смертей від лептоспірозу. Найвищі показники захворюваності та летальності відзначаються у південній та південно-східній Азії, Океанії, на Карибах, у Латинській Америці, східній Афрриці [1]. В Україні хвороба реєструється практично в усіх областях, також і у Тернопільській області.

Ендемічність території з лептоспірозу визначається насамперед наявністю основного природного резервуара збудників - мишоподібних гризунів, а також природнокліматичними умовами (у тому числі кислотністю ґрунтів, кількістю опадів, температурою повітря [2, 3]), які сприяють їх збереженню і розповсюдженню. Джерелом зараження лептоспірозом для людини можуть бути також тварини - і не лише в розпал хвороби, але й довгий час після видужання. Встановлена тривалість лептоспіроносійства у 